\title{
Short-term changes in juvenile hormone titers in honey bee workers due to stress
}

\author{
Huarong LINª ${ }^{\mathrm{a}}$ Candice DUSSET ${ }^{\mathrm{b}}$, Zachary Y. HUANG ${ }^{\mathrm{a} *}$ \\ a Department of Entomology, Michigan State University, East Lansing, MI 48824, USA \\ b Undergraduate Research Opportunity Program Recipient, Michigan State University, East Lansing, \\ MI 48824, USA
}

(Received 9 January 2003; revised 24 July 2003; accepted 31 August 2003)

\begin{abstract}
Juvenile hormone $(\mathrm{JH})$ is well studied in honey bees because it regulates caste determination in immatures and division of labor in adult workers. However it is not clear whether JH titers change significantly under stresses commonly experienced by workers in experimental manipulations. In this study we determined the effect of caging and cold-anaesthesia on $\mathrm{JH}$ titers in both nurses and foragers. The $\mathrm{JH}$ titers of nurses and foragers kept in cages at room temperature, or anaesthetized on ice, for up to 24 hours were determined at various time intervals. Nurses displayed a significant and sustained increase in JH titers by 1-2 hours in 2 out of 3 colonies, regardless whether being cold-anaesthetized or caged. Nurses in 4 out of 4 colonies showed remarkable JH titer elevations 24 hours after being caged. The increase ranged from 3-142 fold compared to their initial baseline JH titers. In foragers, changes in JH titers depended on their initial JH titers: foragers with low JH titers increased while those with high $\mathrm{JH}$ titers decreased. These results suggest that nurses and foragers respond to stress differently. The fact that $\mathrm{JH}$ did not always increase under stress conditions suggests that JH apparently does not function as a "stress-hormone" in honey bees under the two conditions we studied.
\end{abstract}

Apis mellifera / juvenile hormone / radioimmunoassay / stress

Abbreviations: JH Juvenile hormone; RIA radioimmunoassay; CA corpora allata

\section{INTRODUCTION}

Juvenile hormone $(\mathrm{JH})$ plays many roles in honey bees (Apis mellifera L.). JH has been known to be involved in the queen-worker caste differentiation during the larval stage (Rachinsky and Hartfelder, 1990; Rachinsky et al., 1990), in regulating the age-related division of labor in adult workers (reviewed by Robinson, 1992), and in determining aggression levels in workers (Pearce et al., 2001). As one of the most important hormones in insects, $\mathrm{JH}$ is therefore very well studied.

There are three commonly used methods for measuring JH levels in honey bees: gas chromatography and mass spectrometry (GC-MS), radiochemical assay (RCA) and radioimmu- noassay (RIA). In all three methods, there is a delay between the time when bees are removed from their social environment and the time when the relevant measurement is made. For example, because CA removal and haemolymph collection are time consuming, honey bee workers may be left on ice from $20 \mathrm{~min}$ to 2-3 hours before being processed (Huang et al., 1991, 1994). It is not clear whether JH titers measured initially and 3 hours after being anaesthetized on ice are comparable. If JH synthesis by the CA, especially in foragers, is reduced or shut down because of the low temperature they experience, then we expect that the longer the bees remain on ice, the lower their $\mathrm{JH}$ titers will be. This information will provide a guideline for future experiments.

\footnotetext{
* Corresponding author: bees@msu.edu
} 
In this study, we determined JH titers over time in worker bees that experience a "high" stress: being removed from their colony environment and put into a small cage, and those that experience a low stress: bees anaesthetized on ice immediately upon their removal from the colony.

\section{MATERIALS AND METHODS}

\subsection{Bees}

Bees were from colonies maintained according to standard techniques at the Michigan State University Bee Biology Building, East Lansing, Michigan. They were typical of current North American populations of Apis mellifera in the Midwest United States - a mix of predominantly European subspecies (Phillips, 1915; Pellett, 1938). All bees were collected using a portable insect vacuum (Bioquip Products, CA, USA). One group of bees was immediately transferred into Ziploc® bags and buried in ice pellets to be anaesthetized. They typically became immobilized within 2-3 min. We sampled foragers and nurses from two colonies (Colonies 9 and 10) in October 1999. Foragers were identified as bees returning with pollen on their pollen baskets after the hive entrance was blocked with a piece of hardware cloth (Huang and Robinson, 1996). Foragers were painted on their thoraces or abdomen and allowed to go back into the hives. The next day, these pre-marked foragers inside the colony and nurses of unknown ages from frames of open brood were collected at the same time.

In 2000, we sampled three colonies (Colonies 4, 8 and 17). One-day-old (0-24 h post emergence) bees were obtained by incubating sealed brood frames in an incubator $\left(34{ }^{\circ} \mathrm{C}\right.$ and $\left.60 \% \mathrm{RH}\right)$. Before being introduced to their natal colony, they were marked on the thoracic dorsal surface with a paint dot (Testor's PLA) to indicate their age and colony source. Painted marked workers were collected from the center of brood frame when they were 9-11 days old, ages typical of nurses (Winston, 1987). Foragers of unknown age were identified, marked and sampled the same way as in 1999. Foragers and nurses from each colony were sampled at the same time. All five colonies used in this study were each headed by a naturally mated queen and had strengths of 30000 to 45000 workers.

Because data of 2000 to 2001 did not yield a time window for stable $\mathrm{JH}$ titers in nurses (one of two colonies showed significant increase in JH titer in nurses, even at $1 \mathrm{~h}$, the shortest time we tested), in 2002 we sampled haemolymph from nurses in three colonies to see if $\mathrm{JH}$ titers would remain unchanged when anaesthetized on ice for $30 \mathrm{~min}$. Newly emerged workers were marked and reintroduced into their natal colonies. They were then recovered on day 11 , their haemolymph collected immediately, or after being anaesthetized on ice for $30 \mathrm{~min}$.

\subsection{Haemolymph samples}

Ten bees from each hive were bled within $15 \mathrm{~min}$ utes of being removed to provide a baseline of JH titers $(0 \mathrm{~h})$. The rest of this group remained anaesthetized, either on ice, or in a refrigerator $\left(4^{\circ} \mathrm{C}\right)$ until their haemolymph was sampled at predetermined intervals. The second group was kept in either square cages (height $\times$ width $\times$ depth: $15 \times 15 \times 10 \mathrm{~cm}$, in 1999) or plastic cylinder tubes with screen ends (height $\times$ diameter: $12 \times 4.5 \mathrm{~cm}$, in 2000) until the designated time, when they were then anaesthetized on ice and bled within $30 \mathrm{~min}$. Sugar Syrup (50\% v/w) was provided ad libitum on top of each cage. Haemolymph was sampled at set time intervals of 4,8 , and $24 \mathrm{~h}$ after being removed from the colony for both nurses and foragers in 1999. In 2000, foragers were bled at 4,8 and $24 \mathrm{~h}$, and nurses at 1, 2, 3, 4, 8, and $24 \mathrm{~h}$ after removed from their colony. Haemolymph was obtained by placing individual bees under a microscope, pricking a hole on the inter-segmental membrane between the 2nd and 3rd abdominal segment, and collecting the haemolymph with a capillary tube. Haemolymph $(0.4$ to $8.1 \mu \mathrm{L} /$ bee $)$ was measured to the nearest $0.1 \mu \mathrm{L}$ and immediately mixed with $500 \mu \mathrm{L}$ acetonitrile to denature any enzymes that could affect JH. Samples were immediately placed on ice and then stored at $-20{ }^{\circ} \mathrm{C}$ for later $\mathrm{JH}$ analysis. Ten bees were bled at each time interval for each category, except in one colony (Colony 4 ) we only obtained 4 haemolymph samples from caged foragers at $24 \mathrm{~h}$. A total of 870 haemolymph samples were collected for JH analysis.

\subsection{Determination of juvenile hormone titers}

The only form of JH found in honey bees, JH III (Hagenguth and Rembold, 1978) was measured in individual bees using a chiral-specific radioimmunoassay (Hunnicutt et al., 1989). This assay was specifically validated for adult worker honey bees (Huang et al., 1994) and yields comparative JH titers (Huang et al., 1994; Huang and Robinson, 1995) to two other RIAs that were verified with GC-MS (de Kort et al., 1985; Goodman et al., 1990). This procedure was described previously in greater detail (Huang et al., 1994; Huang and Robinson, 1995, 1996). JH in haemolymph samples was extracted twice with hexane and the hexane was evaporated using a vacuum centrifuge linked to a condenser that 
trapped the solvent at $-98{ }^{\circ} \mathrm{C}$ (Savant SS21). Dried $\mathrm{JH}$ was re-dissolved in $50 \mu \mathrm{L}$ methanol and incubation was started by adding a $5 \mu \mathrm{L}$ aliquot of the methanol solution to a $200 \mu \mathrm{L}$ mix of $\mathrm{JH}$ antiserum $(1: 28000)$ and 10000 DPM of $\left[10-{ }^{3} \mathrm{H}(\mathrm{N})\right]-\mathrm{JH}$ (NEN, $629 \mathrm{Gbq} / \mathrm{mmol}$ ). Liquid scintillation counting was performed using a Packard Tricarb 2100TR. Because this represents the first study using an established procedure in a new laboratory setting, we re-determined the intra and inter-assay variations here and they were $10.3 \%$ and $9.2 \%$, respectively $(\mathrm{n}=5)$. These are almost identical to the variations reported previously (10.6\% and $9.2 \%$ ) in another laboratory (Huang et al., 1994). To avoid comparing samples across different days, we analyzed all haemolymph samples of foragers from each colony on the same day. Because of the more frequent sampling (resulting in more samples), we analyzed caged and cold-anaesthetized nurses on separate days.

Capillary tubes and all other glassware that would contact JH were baked at $500{ }^{\circ} \mathrm{C}$ for $3.5 \mathrm{~h}$ prior to use to minimize JH adsorption (Strambi et al., 1981). All solvents were HPLC grade, obtained from VWR Science or Burdick \& Jackson.

\subsection{Statistical analyses}

The experimental design is a Split-Plot Design with Whole-Plot in a Randomized Blocked Design (colony as block). The whole-plot treatment structure is a bee-type $\times$ stress-type factorial. Duration of stress (time since removal) was treated as sub-plot and 10 bees per time point were treated as subsampling. The dependent variable, JH titer, was logtransformed to meet the requirements of parametric analysis. Differences in JH titers for foragers and nurses at different time intervals were first analyzed using SAS (General Linear Model, SAS Institute, 1985). Each stress type (cage or ice) under bee type (foragers or nurses) in a particular colony was analyzed as a one-way ANOVA. If an ANOVA showed an overall significance for a particular colony, we used pre-planned contrasts to determine whether the changes in $\mathrm{JH}$ titers were significant at each time interval compared to the baseline $(0 \mathrm{~h})$. Data from 2002 were tested by t-tests between the two treatments.

\section{RESULTS}

JH titers changed significantly over time after bees were put under stress $\left(\mathrm{F}_{3,586}=37.9\right.$, $P<0.0001)$. Furthermore, JH titers of nurses and foragers changed differently with time (bee-type $\times$ duration interaction: $\mathrm{F}_{3,586}=51.2$, $P=0.05)$. While foragers and nurses showed significantly different $\mathrm{JH}$ titers $\left(\mathrm{F}_{1,9}=9.9\right.$, $P=0.01$ ), the type of stress (being caged vs. being on ice) did not affect $\mathrm{JH}$ titers significantly $\left(\mathrm{F}_{1,9}=0.3, P=0.6\right)$ when all colonies were analyzed together. When we analyzed the data using only the baseline $\mathrm{JH}$ titers at $0 \mathrm{~h}$, we found a significant inter-colony difference of $\mathrm{JH}$ titers $\left(\mathrm{F}_{3,79}=11.5, P<0.0001\right)$. Because of this, below we present a detailed analysis for each type of bee by their stress type for each colony.

\subsection{Cold-anaesthetized nurses}

JH titers in nurses either did not change or significantly increased after workers were removed from colonies and anaesthetized on ice, compared to the baseline JH titers at $0 \mathrm{~h}$ (Fig. 1A). JH titers increased significantly at $4 \mathrm{~h}(\mathrm{~F}=54.9, P<0.0001)$ and $8 \mathrm{~h}(\mathrm{~F}=34.3$, $P<0.0001)$ for Colony 10. The overall ANOVA showed no significance for Colony 4 (F $=0.4, P=0.87$ ), indicating $\mathrm{JH}$ titer at each designated time did not deviate from the baseline. JH titers increased significantly at 2, 3, 4, 8 and $24(\mathrm{~F}=13.5,11.2,28.6,10.42$ and 7.7 , respectively, $P<0.05$ or less) for Colony 8 ; and at $1,2,3,8$ and $24 \mathrm{~h}(\mathrm{~F}=7.8,14.6,5.3,16.4$ and 17.6, $P<0.05$ or less) for Colony 17 .

Data were not available for all samples from Colony 9 and 1 sampling time $(24 \mathrm{~h})$ for Colony 10 due to oil contamination in the hexane used for extractions.

Experiment in 2002 showed that in all 3 colonies, nurses did not show significant increase in JH titers after being anaesthetized on ice for 30 min (mean JH titers \pm standard errors of baseline vs. $30 \mathrm{~min}$ are $63.2 \pm 5.3$ vs. $79.0 \pm$ $15.8,51.6 \pm 5.6$ vs. $55.0 \pm 8.3$, and $28.7 \pm 10.4$ vs. $26.4 \pm 8.0$ for Colonies 11,25 and 35 respectively; t-test, $P>0.05$ for each colony).

\subsection{Caged nurses}

$\mathrm{JH}$ titers in caged nurses showed significant increases in all 4 colonies: at 4,8 and $24 \mathrm{~h}$ $(\mathrm{F}=219.0,264.9$ and 227.2, respectively, $P<$ $0.0001)$ in Colony 10; at $24 \mathrm{~h}$ only $(\mathrm{F}=11.1$, $P<0.002)$ in Colony 4 ; but at $2,3,8$ and $24 \mathrm{~h}$ $(\mathrm{F}=7.7,14.2,10.0$ and 34.6 , respectively, $P<$ 0.01 or less) in Colony 8; and in all time periods (at 1, 2, 3, 4, 8 and $24 \mathrm{~h}: \mathrm{F}=17.2,42.8,24.0$, 28.6, 34.0 and 81.7 , respectively, $P<0.0001$ or 


\section{A: Nurses}

$\square$ Baseline

\section{B: Foragers}

Cold-anaesthetized

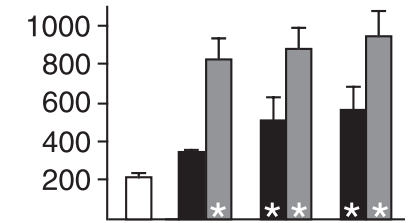

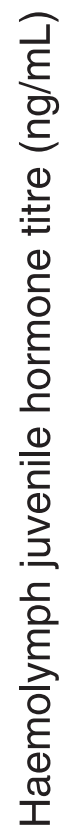

Colony 9 No data for nurses
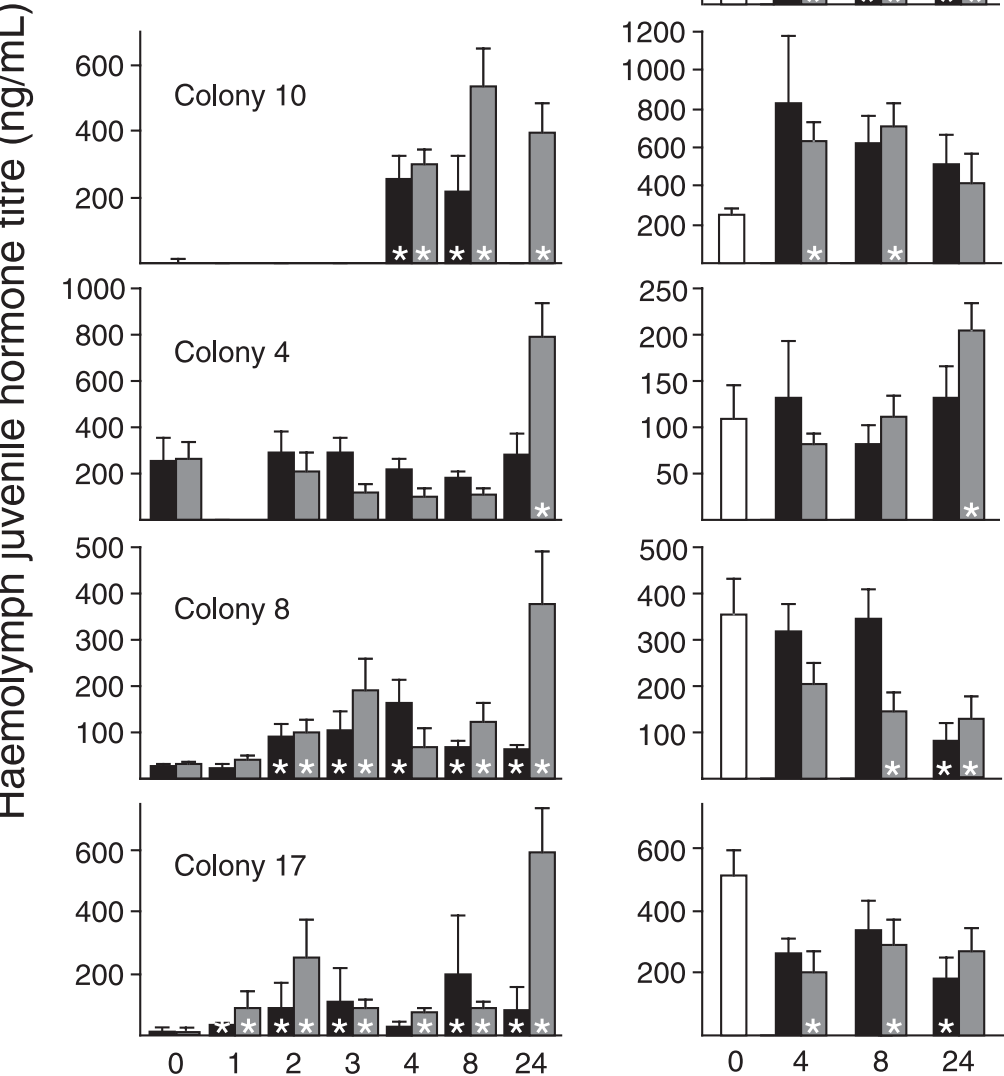

Duration (hours) of stress

Figure 1. Effect of cold anaesthesia and caging on JH titers (mean $\pm \mathrm{SE}$ ). $\mathrm{N}=9-10$ bees per data point (except $24 \mathrm{~h}$ for caged bees in Colony 4 , where $\mathrm{N}=4$ ). A. Nurses, B. Foragers. An asterisk $(*)$ on the bar indicates a significant difference of this time period compared with the baseline $\mathrm{JH}$ titer at $0 \mathrm{~h}$ (at the $5 \%$ level using pre-planned contrasts, following significant overall ANOVA at $P<0.05$ ). For nurses, the baseline $(0 \mathrm{~h})$ samples were analyzed twice by radioimmunoassays, once with the caged bee samples and once with the cold-anaesthetized bee samples, hence two bars (except Colony 10). This was done to remove possible inter assay variations. For foragers, $0 \mathrm{~h}$ samples were analyzed once with all the other samples on the same day and indicated as one open bar for each colony.

less) in Colony 17. The increase of JH titers is the highest at $24 \mathrm{~h}$ after being caged. Compared with their respective baseline $(0 \mathrm{~h}), \mathrm{JH}$ titers in caged nurses increased 142, 3, 12 and 41 times for Colonies 10, 4, 8 and 17, respectively.

\subsection{Cold-anaesthetized foragers}

The pattern of $\mathrm{JH}$ titer changes over time in anaesthetized foragers varied with colony source. (Fig. 1B). JH titers did not change 
significantly in any time period for bees from Colony $10(\mathrm{~F}=2.3, P=0.1)$ or Colony $4(\mathrm{~F}=$ $1.1, P=0.4)$. JH titers increased significantly at 8 and $24 \mathrm{~h}(\mathrm{~F}=5.7$ and $8.0, P=0.02$ and 0.008 , respectively) in bees from Colony $9 . \mathrm{JH}$ titers decreased significantly at $24 \mathrm{~h}(\mathrm{~F}=16.8$, $P=0.0002)$ in Colony 8 , and at $24 \mathrm{~h}(\mathrm{~F}=15.7$, $P=0.0004)$ in Colony 17 .

\subsection{Caged foragers}

Compared to the baseline $\mathrm{JH}$ titers at $0 \mathrm{~h}, \mathrm{JH}$ titers in caged foragers either increased or decreased at various time intervals in different colonies (Fig. 1B). Three colonies showed JH increase after being removed from their colony and put into cages. JH titers increased significantly at 4,8 and $24 \mathrm{~h}(\mathrm{~F}=50.8,56.3$ and 60.6, respectively, $P<0.001$ ) in Colony 9; at 4 and $8 \mathrm{~h}(\mathrm{~F}=9.8$ and $12.9, P=0.003$ and 0.001 , respectively) in Colony 10 . In Colony 4 , the increase is significant only at $24 \mathrm{~h}(\mathrm{~F}=10.08$, $P=0.003)$. JH titers decreased significantly at 8 and $24 \mathrm{~h}(\mathrm{~F}=8.14$ and $4.62, P=0.007$ and 0.04 , respectively) in Colony 8 , and $4 \mathrm{~h}$ and $8 \mathrm{~h}(\mathrm{~F}=12.32$ and $4.27, P=0.001$ and 0.046, respectively) for Colony 17.

\section{DISCUSSION}

This study determined the short-term changes in $\mathrm{JH}$ titers of foragers and nurses that were either caged, or anaesthetized on ice. With the exception of Colony 4, JH titers are low in nurses and high in foragers, consistent with previously published results (Robinson et al., 1989; Huang et al., 1991, 1994). We provide the first evidence that JH titers can change rapidly when workers are removed from their normal social environment and manipulated experimentally. These changes can occur within one hour, even when bees were anaesthetized on ice (Colony 17 in Fig. 1A). Our results indicate that in future experiments, "stress" time must be minimized to avoid experimental artifacts, especially for nurses. Our data suggest that the "safe" time window for bleeding is $30 \mathrm{~min}$ for nurses and less than $4 \mathrm{~h}$ for foragers (Fig. 1B).

Previous studies reported consistently that $\mathrm{JH}$ titers were lower in nurses than in foragers, when haemolymph was collected from bees anaesthetized on ice for 2-3 hours (Huang et al.,
1991, 1994). Because JH titers in nurses can increase significantly after $1-2 \mathrm{~h}$ on ice, while those in foragers remain stable for about $4 \mathrm{~h}$, previously reported $\mathrm{JH}$ titers in nurses was likely overestimated, but the notion that foragers have higher JH titers are still correct. The $\mathrm{JH}$ titer difference between foragers and nurses was not found because of experimental handling, but rather despite of it.

Nurses and foragers responded to stress differently in two different ways. First, nurses are more sensitive to stress brought about by caging and cold anaesthesia. JH titers in nurses changed significantly after 1-2 hours, both when they were placed inside a cage or on ice. In contrast, $\mathrm{JH}$ titers in foragers changed significantly only after 4-24 hours of being caged, or after 24 hours of being on ice. Second, while stress-induced $\mathrm{JH}$ changes in foragers varied among colonies, JH titers in nurses always increased. For example, 24 hours after being caged, nurses in 4 colonies all showed $\mathrm{JH}$ titer elevations, the increase ranged from 3 to 142 fold compared to their initial baseline JH titers.

Recently, it was discovered that $\mathrm{JH}$ levels in foragers also show diurnal changes. JH titers were at their lowest just before noon, slightly increased by late afternoon and peaked just before midnight (Elekonich et al., 2001). The short-term changes we observed in this study, however, seem to be independent of the diurnal changes. All bees were collected between 9:00 to 11:00 in our study. However, the JH titers in caged foragers either decreased (Colonies 8 and 17), or increased (Colony 9). JH titers did not show any coordinated changes with time, as would be expected if the changes that we observed were related to diurnal changes. It is not clear whether the changes we observed were superimposed on the diurnal changes in JH titers, or because our bees were experimentally manipulated, the naturally occurring diurnal changes were abolished and the observed $\mathrm{JH}$ changes here are only a response to experimental manipulations.

$\mathrm{JH}$ titers are regulated by the changes in rate of $\mathrm{JH}$ biosynthesis and other processes, such as degradation and tissue uptake (reviewed by Tobe and Stay, 1985). In this study JH titers in caged foragers either did not change, increased, or deceased, but in nurses the changes were always positive (increases). It appears that in our data (Fig. 1A and B) the directions of $\mathrm{JH}$ 
titer change depended on the initial JH titers. If the baseline $\mathrm{JH}$ titers were low (under $200 \mathrm{ng} / \mathrm{ml}$, foragers in Colonies 4, 9 and 10; nurses in all colonies), then the change was positive (increase). In contrast JH titers decreased if the baseline titers were high (over $300 \mathrm{ng} / \mathrm{ml}$, foragers in Colonies 8 and 17). Furthermore, this pattern did not depend on whether the workers were stressed by cold-anaesthesia or by caging although foragers showed slightly more sensitivity to caging than cold-anaesthesia. Mechanisms of these $\mathrm{JH}$ changes under stress are unknown, but it is possible the balance between source ( $\mathrm{JH}$ production) and sink (degradation or uptake), which might be different depending on initial JH titers, changes differently when under stress. If bees have a high baseline $\mathrm{JH}$ titer, $\mathrm{JH}$ production decreases or degradation/uptake increases under stress, then $\mathrm{JH}$ titer decreases. If bees have a low baseline JH titer, JH production increases or degradation/uptake declines under stress, then JH titer increases. These alternative hypotheses for "under stress" changes of production or degradation/uptake can be separated only if one studies the JH titers, JH biosynthesis and $\mathrm{JH}$ degradation simultaneously in bees under stress. Huang and Robinson (1995) studied the change of $\mathrm{JH}$ biosynthesis and $\mathrm{JH}$ titers in the same bees before and after cold-treatment. Their results also fit our hypothesized changes. Foragers showed a reduction in both JH biosynthesis and $\mathrm{JH}$ titers while nurses, which had lower JH levels, showed no such changes. Rauschenbach et al. (1995) observed that female Drosophila from different genetic lines responded differently to heat stress, with either a decrease or no change in JH-esterase activity. These changes then resulted in either an increase or no change in JH titers (Rauschenbach, 1991). It remains to be determined whether the JH titer changes (whether naturally or under stress) in the honey bees can be attributed to changes in the degradation system. In contrast to the well-studied $\mathrm{JH}$ biosynthesis and $\mathrm{JH}$ titers, JH degradation in adult honey bees remains virtually unstudied. In two studies that determined JH degradation in honey bee larvae, degradation was found to be much lower than is commonly observed in other insects (de Kort et al., 1977; Mane and Rembold, 1977).

The high levels of variation in forager JH titers we see here are consistent with previous findings (Huang and Robinson, 1995), but this study also shows a high variation of JH titers in nurses. Rates of JH biosynthesis do not seem to show the same level of inter-colony variation (Huang and Robinson, 1995), suggesting that variation in JH degradation or uptake might be responsible for the higher variation of titers among colonies.

There is evidence that $\mathrm{JH}$ functions as "stress" hormone in fruitflies. JH titers increase in female Drosophila adults when they are under heat stress (Rauschenbach, 1991), due to a decrease in JH-esterase activity (Rauschenbach et al., 1995). Our data here suggest that JH does not function as a "stress-hormone" in honey bees, because $\mathrm{JH}$ titers changed in different directions, which is not expected if it were a stress hormone. In addition, while there are small differences in time-course or magnitude for caged and cold-anaesthetized bees to show $\mathrm{JH}$ titer differences compared to the baseline, in general the patterns are similar under the two different stressing conditions (see Fig. 1A and $\mathrm{B}$ for Colonies 10, 4, 8, and 17). We expected that bees would always show JH titer increase under caged conditions, and that the increase would be greater in magnitude than bees under cold-anaesthesia, because we hypothesized that bees in cages would be under a stronger stress stimulus. Fully active caged bees would be able to adjust their behavior or physiology more quickly. Whereas, "unconscious" coldanaesthetized bees might not be able to perceive the social stress but only the temperature change. The notion that $\mathrm{JH}$ does not function as a stress hormone in honey bees is also supported by previously published data showing that JH decreased in foragers under two different kinds of stresses. When a colony was moved into a cold room in summer and subjected to cold stress for 8 days, JH titers (and rates of biosynthesis) significantly decreased in foragers (Huang and Robinson, 1995). In a "reversion" experiment, all nurses and other young bees were removed from a colony, presumably exerting a high level of social stress on the foragers left behind. However under these conditions, foragers who previously had high JH titers showed a remarkable drop in $\mathrm{JH}$ within 24 hours (Huang and Robinson, 1996), instead of an expected increase.

One colony in our study did not fit the pattern of low $\mathrm{JH}$ in nurses and high $\mathrm{JH}$ in foragers. $\mathrm{JH}$ 
titers in nurses $(251 \pm 94)$ were as high as foragers $(108.1 \pm 37)$ in Colony $4(\mathrm{t}=1.3, P=0.2)$. This colony seems to be unusual because such high JH titers in nurses have not been observed previously despite many studies (Robinson et al., 1987, 1989; Huang et al., 1991, 1994; Huang and Robinson, 1995; Jassim et al., 2000). One possibility is that the foragers we sampled were from a different paternal group than the nurses. A queen mates with up to 717 different drones (reviewed by Page, 1986) and there is slight sperm fluctuation from month to month (Franck et al., 1999). Another possibility is that the nurses we sampled were a mixture of foragers and nurses due to fast development of the bees. We did observe foraging in this marked group of "nurses", despite their young age (10 days post emergence), suggesting that this group was a mix of foragers and nurses. This further strengthens the need for a sample size of at least 4-5 honey bee colonies (as we have done here), because of the high inter-colony variation that may exist in any ecological or physiological study.

\section{ACKNOWLEDGMENTS}

We thank Micah Gill and Joerg Schmidt-Bailey for help in maintaining bee colonies, Anne Hanley for help in bleeding bees for haemolymph samples, D.W. Borst of Illinois State University for graciously providing the juvenile hormone antiserum for the radioimmunoassay and George Sirbu for providing advice for statistical analysis. We thank George Ayers, Erik Foster, Anne Hanley, Noah Koller, Walter Pett, Therese Poland and three anonymous reviewers for their comments to improve this manuscript. This work was supported by a USDA grant (AG 97-35302-5304) and a grant from the Michigan Department of Agriculture to ZYH and an UROP (Undergraduate Research Opportunity Program) scholarship from Michigan State University to $C D$.

Résumé - Changement à court terme dû au stress du taux d'hormone juvénile chez les ouvrières d'abeilles. De par son rôle dans le déterminisme des castes (reine/ouvrière) au cours du développement larvaire et dans la division du travail chez les abeilles adultes, l'hormone juvénile (HJ) est bien étudiée chez l'Abeille domestique (Apis mellifera L.). Par contre on ne sait pas si le taux de HJ varie de façon significative lorsque les manipulations expérimentales provoquent du stress chez les abeilles. Peut-on par exemple laisser des abeilles sur de la glace pendant $24 \mathrm{~h}$ sans que leur taux de HJ ne soit modifié ? Si tel est le cas, cela laisserait plus de liberté aux expérimentateurs pour faire des recherches. Si en revanche le taux d'HJ se modifie après seulement $2 \mathrm{~h}$ de séjour sur la glace, il faut avoir prélevé l'hémolymphe des abeilles en moins de $2 \mathrm{~h}$. Si le taux d'HJ ne se modifie pas lorsque les abeilles sont encagées, ce procédé peut remplacer l'anesthésie par la glace. Dans cette étude le taux d'HJ de nourrices et de butineuses, encagées à la température ambiante ou anesthésiées sur la glace durant $24 \mathrm{~h}$ ou moins a été déterminé à intervalles réguliers grâce à une méthode radioimmunologique hautement spécifique.

Les nourrices et les butineuses ont réagi différemment au stress et de deux façons. Premièrement les nourrices sont plus sensibles au stress induit par l'encagement et l'anesthésie par le froid ; chez la plupart d'entre elles, le taux d'HJ s'est significativement modifié au bout d' 1 à $2 \mathrm{~h}$. Au contraire le taux d'HJ des butineuses n'a changé significativement qu'après 4 à $24 \mathrm{~h}$ d'encagement ou après $24 \mathrm{~h}$ de séjour sur la glace. Deuxièmement, tandis que les changements dans le taux d'HJ induit par le stress varient d'une colonie à l'autre pour les butineuses (certains augmentent, d' autres baissent, d' autres restent stables), chez les nourrices le taux d'HJ augmente toujours (sauf pour la colonie 4, dont le taux est resté stable au cours de l'anesthésie). Par exemple, les nourrices de quatre colonies ont toutes vu leur taux d'HJ augmenter au bout de $24 \mathrm{~h}$ d'encagement ; sa valeur a été comprise entre 3 fois à 142 fois celle de départ. Pour les butineuses, le changement dépend du taux initial d'HJ. Si la valeur de départ est faible (moins de $20 \mathrm{ng} / \mathrm{mL}$, butineuses des colonies 4,9 et 10 et nourrices de toutes les colonies), le taux d'HJ augmente. Au contraire il diminue si la valeur de départ était élevée (plus de $30 \mathrm{ng} / \mathrm{mL}$, butineuses des colonies 8 et 17).

Nous en concluons que les nourrices et les butineuses répondent au stress provoqué par l'encagement ou l'anesthésie par la glace en modifiant leur taux d'HJ. Cela peut être un problème pour déterminer le taux d'HJ si l'hémolymphe n'est pas prélevée dès que les abeilles sont extraites de leur milieu social. Pour les nourrices la plage de sécurité est de $30 \mathrm{~min}$ après qu'elles sont sorties de la colonie et mises sur la glace; pour les butineuses le taux resterait stable pendant $4 \mathrm{~h}$. Notre étude suggère aussi qu' apparemment l'HJ ne fonctionne pas comme « hormone de stress » chez les abeilles dans les deux conditions que nous avons étudiées, puisque le taux d'HJ n'a pas toujours augmenté lorsque les abeilles étaient encagées ou anesthésiées sur la glace.

Apis mellifera / hormone juvénile / stress / méthode radioimmunologique

Zusammenfassung - Stressbedingte kurzzeitige Veränderungen im Juvenilhormon-Titer von Arbeiterinnen der Honigbiene. Juvenilhormon $(\mathrm{JH})$ in Honigbienen (Apis mellifera L.) ist aufgrund 
seiner Königinnen- und Arbeiterinnen-determinierenden Funktion in Entwicklungsstadien und seiner Rolle in der Arbeitsteilung adulter Arbeiterinnen gut untersucht. Unklar ist allerdings, ob der JH-Titer Veränderungen aufweisen kann, wenn Arbeiterinnen Stresssituationen ausgesetzt sind, die denen einer typischen experimentellen Manipulation entsprechen. Können wir beispielsweise Bienen für 24 Stunden auf Eis halten, ohne dass sich ihr JH-Titer verändert? Sollte dies der Fall sein, könnten Experimente unter wesentlich größeren Freiheitsgradbedingungen durchgeführt werden. Sollten andererseits bereits nach nur zwei Stunden auf Eis bereits Änderungen im JH-Titer auftreten, so müsste die Hämolymphentnahme bereits in einem Zeitrahmen unter zwei Stunden erfolgen. Sollte sich der JH-Titer nach der Käfigung von Arbeiterinnen nicht ändern, dann könnte ein solches Verfahren eine Anästhesie auf Eis ersetzen. In der vorliegenden Studie bestimmten wir die Effekte einer Käfigung und einer Kälteanästhesie bei Ammenbienen und Sammlerinnen. Die JH-Titer solcher Ammenbienen und Sammlerinnen, die für bis zu 24 Stunden entweder bei Raumtemperatur gekäfigt gehalten oder auf Eis anästhesiert wurden, bestimmten wir in unterschiedlichen Zeitintervallen mittels eines hochspezifischen Radioimmunoassay.

Ammenbienen und Sammlerinnen wichen in ihrer Stressantwort in zwei Richtungen ab. Erstens reagierten Ammenbienen deutlich sensitiver auf den Käfigungs- und Kälteanästhesiestress. In beiden Situationen zeigten die JH-Titer von Ammenbienen bereits nach 1-2 Stunden signifikante Abweichungen. Im Gegensatz hierzu waren im JH-Titer von Sammlerinnen erst nach 4-24 Stunden Käfigung und erst nach 24 Stunden auf Eis signifikante Änderungen im JH-Tier zu sehen. Zweitens zeigte der JHTiter von Sammlerinnen unter Stress ganz erhebliche koloniebedingte Abweichungen (in einigen Fällen trat ein Titeranstieg, in anderen ein Abfall ein und in wieder anderen blieb der Titer unverändert), während bei Ammenbienen stets ein Titeranstieg zu beobachten war (außer bei Ammen von Volk 4, deren Titer unter Eisanästhesie unverändert blieb). Beispielsweise erwiesen sich bei Ammenbienen nach einer 24-stündigen Käfigung in allen vier Völkern die JH-Titer als erhöht, wobei es sich hierbei um eine drei- bis 142-fache Steigerung im Vergleich zu den Ausgangstiterwerten handeln konnte. Bei Sammlerinenn war die Richtung der Veränderung im JHTiter stark von dessen Ausgangswerten abhängig. In Fällen, in denen der anfängliche JH-Titer niedrig war (unter $200 \mathrm{ng} / \mathrm{ml}$ bei Sammlerinnen der Völker 4, 9 und 10, und bei Ammenbienen in allen Fällen), erfolgte die Veränderung immer in eine positive Richtung (Titeranstieg). Im Gegensatz hierzu war in Fällen hoher Ausgangstiterwerte (über $300 \mathrm{ng} / \mathrm{ml}$, bei Sammlerinnen der Völker 8 und 17) ein Titerabfall zu beobachten.

Wir schliessen hieraus, dass sowohl bei Ammenbienen als auch bei Sammlerinnen die Stressantwort (bei Käfigung bei Raumtemperatur oder bei Anäs- thesie auf Eis) eine Veränderung im JH-Titer beinhaltet. Dies kann ein Problem darstellen, wenn Bienen für JH-Titerbestimmungen gesammelt werden, die Hämolymphe jedoch nicht sofort nach Entnahme der Bienen aus ihrer sozialen Umgebung gewonnen wird. Bei Ammenbienen liegt der sichere Zeitrahmen bei 30 min, wenn sie auf Eis gehalten werden, bei Sammlerinenn bleibt der JH-Titer bei einer bis $\mathrm{zu}$ vierstündigen Anästhesie auf Eis konstant. Unsere Ergebnisse deuten auch darauf hin, dass $\mathrm{JH}$ bei Honigbienen unter den beiden von uns untersuchten Bedingungen keine Funktion als eigentliches "Stresshormon" zu haben scheint, da die JHTiter bei Sammlerinnen nur in einigen Fällen einen Anstieg zeigten, wenn diese entweder gekäfigt waren oder auf Eis anästhesiert wurden.

\section{Apis mellifera / Juvenilhormon / Radioimmu- noassay / Stress}

\section{REFERENCES}

de Kort C.A.D., Wieten M., Kramer S.J., Goewie E. (1977) Juvenile hormone degradation and carrier proteins in honey bee larvae, Proc. Kon. Ned. Akad. Wet. 80C, 297-301.

de Kort C.A.D., Koopmanschap A.B., Strambi C., Strambi. A. (1985) The application and evaluation of a radioimmunoassay for measuring juvenile hormone titers in Colorado beetle haemolymph, Insect Biochem.15, 771- 775.

Elekonich M.M, Schulz D.J., Bloch G., Robinson G.E. (2001) Juvenile hormone levels in honey bees (Apis mellifera L.), J. Insect Physiol. 47, 1119-1125.

Franck P., Coussy H., Le Conte Y., Solignac M., Garnery L., Cornuet J.-M. (1999) Microsatellite analysis of sperm mixture in honeybee, Insect Mol. Biol. 8, 419- 421.

Goodman W.G., Coy D.C., Baker F.C., Xu L., Toong Y.C. (1990) Development and application of a radioimmunoassay for the juvenile hormones, Insect Biochem. 20, 357-364.

Hagenguth H., Rembold H. (1978) Identification of juvenile hormone III as the only juvenile hormone homolog in all developmental stages of the honey bee, Z. Naturforsch. 33C, 847-850.

Huang Z.-Y., Robinson G.E. (1995) Seasonal changes in juvenile hormone titers and rates of biosynthesis in honey bees, J. Comp. Physiol. B 165, 1828.

Huang Z.-Y., Robinson G.E. (1996) Regulation of honey bee division of labor by colony age demography, Behav. Ecol. Sociobiol. 39, $147-$ 158.

Huang Z.-Y., Robinson G.E., Tobe S.S., Yagi K.J., Strambi C., Strambi A., Stay B. (1991) Hormonal regulation of behavioral development in the honey bee is based on changes in the rate of 
juvenile hormone biosynthesis, J. Insect Physiol. 37, 773-741.

Huang Z.-Y., Robinson G.E., Borst D.W. (1994) Physiological correlates of division of labor among similarly aged honey bees, J. Comp. Physiol. A 174, 731- 739.

Hunnicutt D., Toong Y.C., Borst D.W. (1989) A chiral specific antiserum for juvenile hormone, Am. Zool. 29, 48a.

Jassim O., Huang Z.Y., Robinson G.E. (2000) Juvenile hormone profiles of worker honey bees, Apis mellifera, during normal and accelerated behavioural development, J. Insect Physiol. 46, 243- 249.

Mane S.D., Rembold H. (1977) Developmental kinetics of juvenile hormone inactivation in quen and worker castes of the honey bee, Apis mellifera, Insect Biochem. 7, 463-467.

Page R.E. (1986) Sperm utilization in social insects, Annu. Rev. Entomol. 31, 297-320.

Pearce A.N., Huang Z.Y., Breed M.D. (2001) Juvenile hormone and aggression in honey bees, $\mathrm{J}$. Insect Physiol. 47, 1243- 1247.

Pellet F.C. (1938) History of American beekeeping, Collegiate Press, Ames, IA.

Phillips E.F. (1915) Beekeeping, MacMillan, New York.

Rachinsky A., Hartfelder K. (1990) Corpora allata activity, a primer regulating element for caste juvenile hormone titer in honey bee larvae (Apis mellifera carnica), J. Insect Physiol. 36, 189194.

Rachinsky A., Strambi A., Hartfelder K. (1990) Caste and metamorphosis: haemolymph titers of juvenile hormone and ecdysteoids in last instar honey bee larvae, Gen. Comp. Endocrinol. 79, 31- 38.
Rauschenbach I.Y. (1991) Changes in ecdisteroid and juvenile hormone under heat stress, in: Ivanovic J., Jancovic-Hladni M. (Eds.), Hormones and metabolism in insect, CRC Press, Boca Raton, Ann Arbor, Boston, pp. 115- 148.

Rauschenbach I.Y., Khlebodarova T.M., Chentsova N.A., Grountenko N.E., Grenback L.G., Yantsen E.I., Filipenko M.I. (1995) Metabolism of the juvenile hormone in Drosophila adults under normal conditions and heat stress: general and biochemical aspects, J. Insect Physiol. 41, 179189.

Robinson G.E. (1992) Regulation of division of labor in insect societies, Annu. Rev. Entomol. 37, 637665.

Robinson G.E., Strambi A., Strambi C., PaulinoSimoes Z.L., Tozeto S., Barbosa J.M.N. (1987) Juvenile hormone titers in European and Africanized honey bees in Brazil, Gen. Comp. Endocrinol. 66, 457-459.

Robinson G.E., Page R.E., Strambi A., Strambi C. (1989) Hormonal regulation of behavioral integration in honey bee colonies, Science 246, 109 112.

SAS Institute Inc. (1985) SAS user's guide: Statistics, Carry, North Carolina.

Strambi C., Strambi A., de Reggi M., Hirn M., Delaage M. (1981) Radioimmunoassay of insect juvenile hormone and of their diol derivatives, Eur. J. Biochem. 118, 401- 406.

Tobe S.S., Stay B. (1985) Structure and regulation of the corpus allatum, Adv. Insect Physiol. 18, 306432.

Winston M.L. (1987) The Biology of the honey bee, Harvard University Press: Cambridge, MA. 